О.В. Курбатова ${ }^{1}$, Т.Д. Измайлова ${ }^{1}$, А.Н. Сурков ${ }^{1}$, Л.С. Намазова-Баранова ${ }^{1,2,3}$, С.И. Полякова ${ }^{1}$, Л.В. Мирошкина ${ }^{1}$, Г.Ф. Семёнова ${ }^{1}$, И.В. Самохина ${ }^{1}$, Е.Ю. Капустина ${ }^{1}$, 3.Н. Духова ${ }^{1}$, А.С. Потапов ${ }^{1,2}$, С.В. Петричук ${ }^{1}$

\footnotetext{
${ }^{1}$ Научный центр здоровья детей, Москва, Российская Федерация

2 Первый Московский государственный медицинский университет им. И.М. Сеченова, Российская Федерация ${ }^{3}$ Российский национальный исследовательский медицинский университет им. Н.И. Пирогова, Москва, Российская Федерация

\section{Митохондриальная дисфункция у детей с печеночными формами гликогеновой болезни}

\begin{abstract}
Цель исследования: оценить характер митохондриальных дисфункций у детей с печеночными формами гликогеновой болезни (ГБ). Пациенты и методы: в динамике обследовано 53 ребенка с ГБ, которые в зависимости от типа заболевания были распределены на 3 группы: 1-я - дети с ГБ типа I; 2-я - с ГБ типа III; 3-я - с ГБ типа VI и IX. Группу сравнения составили 34 условно здоровых ребенка. Активность внутриклеточных дегидрогеназ: сукцинатдегидрогеназы (СДГ), глицерол-3-фосфатдегидрогеназы (ГФДГ), никотинамидаденин-Н-дегидрогеназы (НАДН-Д) и лактатдегидрогеназы (ЛДГ) определяли количественным иитохимическим методом в лимфоцитах периферической крови. Результаты: обнаружено снижение активности СДГ ( $p<0,001)$ и ГФДГ $(p<0,001)$ на фоне повышения активности НАДН-Д ( $p<0,05)$, а также снижение индекса СДГ / НАДН-Д ( $<$ <0,001) у всех пациентов с ГБ. Активность ЛДГ по отношению к группе сравнения была повышена в 1-й $(p<0,05)$ и 3-й $(p<0,01)$ группе. Наиболее выраженные изменения активности внутриклеточных дегидрогеназ имели место у детей с ГБ типа I, что соответствует более тяжелому клиническому течению данной формы патологии. Установлено, что активность внутриклеточных дегидрогеназ лимфоцитов сильно коррелирует с выраженностью гепатомегалии $(R=0,86)$ и степенью метаболического ацидоза $(R=0,987)$. Выводы: у детей с печеночными формами ГБ обнаружены признаки митохондриальной дисфункиии, степень выраженности которых зависит от типа заболевания. Активность ферментов лимфоцитов коррелирует с основными параметрами оценки тяжести состояния, что позволяет использовать данные показатели в качестве дополнительных диагностических критериев у детей с ГБ. Ключевые слова: дети, митохондриальная дисфункиия, гликогеновая болезнь, внутриклеточные дегидрогеназы. (Вестник РАМН. 2014; 7-8: 78-84)
\end{abstract}

\section{Введение}

Гликогеновая болезнь (ГБ) - обобщающее название группы редких наследственных заболеваний, об- условленных недостаточностью различных ферментов, участвующих в обмене гликогена. Энзимные дефекты приводят к нарушениям его структуры и избыточному накоплению в различных тканях и органах. В зависимо-

O.V. Kurbatova ${ }^{1}$, T.D. Izmailova ${ }^{1}$, A.N. Surkov ${ }^{1}$, L.S. Namazova-Baranova ${ }^{1,}$, ${ }^{3}$, S.I. Polyakova ${ }^{1}$, L.V. Miroshkina ${ }^{1}$, G.F. Semyonova1 ${ }^{1}$, I.V. Samokhina1 ${ }^{1}$, E.Yu. Kapustina ${ }^{1}$, Z.N. Dukhova, A.S. Potapov', ${ }^{1}$, S.V. Petrichuk ${ }^{1}$

${ }^{1}$ Scientific Centre of Children Health, Moscow, Russian Federation

${ }^{2}$ I.M. Sechenov First Moscow State Medical University, Russian Federation

${ }^{3}$ N.I. Pirogov Russian National Research Medical University, Moscow, Russian Federation

\title{
Mitochondrial Dysfunction in Children with Hepatic Forms of Glycogen Storage Disease
}

Aim: The purpose of the study was to assess mitochondrial dysfunction severity in patients with hepatic forms of glycogen storage disease (GSD). Patients and methods: We examined 53 children with GSD in the dynamics. Distribution of children by disease types was: $1^{\text {st }}$ group - children with GSD type I, $2^{\text {nd }}$ group - children with GSD type III, $3^{\text {rd }}$ group - children with GSD type VI and IX; comparison group consisted of 34 healthy children. Intracellular dehydrogenases activity: succinate dehydrogenase (SDH), glycerol-3-phosphate-dehydrogenase (GPDH), nicotinamideadenin- $H$-dehydrogenase $(N A D H-D)$ and lactatdehydrogenase $(L D H)$ was measured using the quantitative cytochemical method in the peripheral lymphocytes. Results: It was revealed decrease of SDH- $(p<0.001)$ and GPDH-activities $(p<0.001)$, along with increase of the NADH-D activity $(p<0.05)$ in all patients with GSD, (SDH / NADH-D) index was decreased $(p<0.001)$. LDH activity was increased in groups $1(p<0.05)$ and $3(p<0.01)$, compared with comparison group. The most pronounced intracellular enzymes activity deviations were observed in children with GSD type I, that correspond to more severe clinical form of GSD. It was found strong correlation between intracellular enzymes activity and both hepatomegaly level $(R=0.867)$ and metabolic acidosis severity $(R=0.987)$. Conclusion: Our investigation revealed features of mitochondrial dysfunction in children with GSD, depending on the GSD type. Activities of lymphocytes enzymes correlates with the main disease severity parameters and can be used as an additional diagnostic criteria in children with hepatic form of GSD.

Key words: children, mitochondrial dysfunction, glycogen storage disease, intracellular dehydrogenases.

(Vestnik Rossiiskoi Akademii Meditsinskikh Nauk - Annals of the Russian Academy of Medical Sciences. 2014; 7-8: 78-84) 
сти от недостатка того или иного фермента, а также от типа поражаемой ткани, в настоящее время выделяют до 15 типов заболевания [1]. В данной работе речь пойдет о тех типах ГБ, которые протекают с преимущественным поражением печени(тип I, III, VI и IX).

Среди вариантов ГБ типа I выделяют 2 основных. Подтип Іа развивается в результате мутаций гена $G 6 P C$, кодирующего глюкозо-6-фосфатазу, что приводит к ее недостаточности в клетках печени, почек, слизистой оболочке кишечника, желчного пузыря, а также в $\beta$-клетках поджелудочной железы. ГБ подтипа Ib обусловлена мутациями гена $S L C 17 A 4$, кодирующего микросомальный транспортный белок Т1 (транслоказу глюкозо6-фосфатазы), которые приводят к его недостаточности в печени, почках, слизистой оболочке кишечника. ГБ типа I характеризуется наиболее тяжелым течением в связи с наибольшей выраженностью метаболических нарушений [1-5].

ГБ типа III возникает в результате мутаций гена $A G L$, кодирующего гликоген-деветвящий фермент, который представлен двумя каталитическими единицами: амило1,6-глюкозидазой и 4- $\alpha$-глюканотрансферазой [1, 3-5]. Течение этой формы патологии различно: имеют место случаи прогрессирования заболевания или, наоборот, регресс симптоматики с возрастом.

ГБ типа VI обусловлена мутациями гена $P Y G L$, кодирующего фосфорилазу печени, дефицит которой ведет к избыточному накоплению гликогена в гепатоцитах. ГБ типа IX возникает в результате различных дефектов фосфокиназной системы. У пациентов с VI и IX типом ГБ имеет место наиболее легкий вариант течения заболевания [1, 3-5].

Поскольку первичный ферментный дефект связан с нарушением образования глюкозы из гликогена, ведущим метаболическим симптомом при ГБ является гипогликемия, степень выраженности которой, соответственно, и определяет состояние больных. Таким образом, в результате генетических мутаций, ведущих к возникновению ГБ, происходят и изменения различных жизненноважных биохимических процессов, связанных с нарушениями углеводного обмена. Это отрицательно отражается на образовании энергоемких соединений, что в рамках современных молекулярно-биологических исследований рассматривается как митохондриальная дисфункция.

Рядом авторов показано, что митохондриальная дисфункция лежит в основе широкого диапазона патологических процессов, являющихся отправной точкой для развития различных патологий: нарушения врожденного иммунного ответа, аутовоспалительных заболеваний, хронических дегенеративных и опухолевых заболеваний [6-11].

Несмотря на то, что наибольшее внимание в рамках митохондриальной медицины уделяют первичной (генетически детерминированной) митохондриальной патологии, тем не менее и первичные, и вторичные митохондриальные расстройства имеют аналогичные формы реализации на клеточном уровне $[10,11]$. Таким образом, выявление характера и степени митохондриальных нарушений становится актуальной диагностической проблемой.

Для оценки функционального состояния митохондриального аппарата возможно использовать определение активности ферментов дыхательной цепи: сукцинатдегидрогеназы (СДГ) и никотинамидаденин-Н-дегидрогеназы (НАДН-Д) лимфоцитов периферической крови.

СДГ - основной фермент цикла Кребса и этапа II дыхательной цепи митохондрий. Это флавопро- теид, прочно связанный с внутренней мембраной митохондрий. В цикле трикарбоновых кислот СДГ катализирует окисление янтарной кислоты в фумаровую и позволяетс высокой степенью достоверности судить о функциональности всего митохондриального аппарата. НАДН-Д - комплекс никотинамидаденин-зависимых дегидрогеназ (НАДН-цитохром С-редуктаза, липоилдегидрогеназа, хинонредуктаза), которые катализируют перенос водорода с НАДН на флавинмононуклеотид. Этот комплекс - один из начальных компонентов дыхательной цепи, по которой осуществляется переход электронов от субстрата к кислороду, и которая неразрывно функционально связана с работой цикла Кребса. Определение активности НАДН-дегидрогеназы дает представление об интенсивности работы этапа I дыхательной цепи митохондрий

Доказано, что наиболее ранним ответом на гипоксическое воздействие является усиление интенсивности НАДН-зависимого пути окисления и его вклада в обшее дыхание. Активация НАД-зависимого окисления сопровождается, как правило, повышением интенсивности образования АТФ. Эту стадию рассматривают как первичную срочную неспецифическую компенсаторную реакцию энергетического аппарата на снижение доставки кислорода к клетке, в основе которой лежат такие же изменения, как и при рабочей гипоксии или гипоксии напряжения [12]. В некоторых исследованиях, посвященных течению аллергических заболеваний, воспалительных заболеваний кишечника, перитонита и др., показана информативность цитохимического индекса - соотношение СДГ / НАДН-Д [13-15].

Интенсивность процессов гликолиза принято оценивать по активности лактатдегидрогеназы (ЛДГ) фермента, катализирующего обратимое восстановление пировиноградной кислоты до молочной в процессе анаэробного гликолиза.

Сопряженность гликолиза и цикла Кребса определяют по активности митохондриальной глицерол3-фосфатдегидрогеназы (ГФДГ) - фермента, отражающего работу глицерофосфатного челночного механизма по транспорту электрон-эквивалентов из цитоплазмы в митохондрии, а также обмен фосфолипидов.

В настоящее время оценка митохондриальных дисфункций широко используется при различных патологических состояниях [16-19], однако исследования этой проблемы при ГБ ограничиваются единичными зарубежными публикациями [20, 21]. В доступной отечественной литературе сведений по данному вопросу нами обнаружено не было.

С учетом того, что при ГБ у пациента исходно существует метаболический дефект, являющийся провоцирующим фактором для развития митохондриальной дисфункции, которая, в свою очередь, усугубляет тяжесть состояния больного, становится очевидной необходимость использования специфических методов диагностики, позволяющих оценить характер и степень выраженности вероятных митохондриальных нарушений.

Цель исследования: изучить характер митохондриальных нарушений у детей с печеночными формами гликогеновой болезни.

\section{Пациенты и методы}

\section{Участники исследования}

В динамике обследовано 53 ребенка (33 мальчика и 20 девочек) с ГБ, которые составили основную группу. 
Таблица 1. Показатели активности сукцинат- и никотинамидаденин-Н-дегидрогеназы лимфоцитов и их соотношение у пациентов 1-й, 2-й и 3-й подгруппы по отношению к группе сравнения

\begin{tabular}{|l|c|c|c|c|}
\hline \multicolumn{1}{|c|}{ Показатель } & Группа сравнения $(\boldsymbol{n = 1 0 7 )}$ & $\mathbf{1 - я ~ п о д г р у п п а ~}(\boldsymbol{n}=\mathbf{4 4})$ & 2-я подгруппа $(\boldsymbol{n}=\mathbf{2 5})$ & $\mathbf{3 - я ~ п о д г р у п п а ~}(\boldsymbol{n}=\mathbf{3 8})$ \\
\hline СДГ & $987[931-1043]$ & $811^{*}[649-1002]$ & $821^{*}[779-982]$ & $927 *[772-1027]$ \\
\hline НАДН-Д & $738[690-818]$ & $775^{* *}[554-999]$ & $778^{* *}[699-911]$ & $788^{* *}[620-1019]$ \\
\hline СДГ / НАДН-Д & $1,35[1,20-1,42]$ & $1,01 *[0,86-1,35]$ & $1,04 *[0,97-1,24]$ & $1,12 *[0,96-1,34]$ \\
\hline
\end{tabular}

Примечание. * ${ }^{*} p<0,001 ; * *-p<0,05$.

Возраст пациентов колебался от 13 мес до 17 лет; медиана возраста составила 7,6 [4,1; 10,8] лет.

В зависимости от типа заболевания, в составе основной группы было выделено 3 подгруппы: 1-я - дети с ГБ типа I $\left(n_{\text {детей }}=19, n_{\text {обследований }}=44\right) ; 2-я-$ дети с ГБ типа III, $\left(n_{\text {детей }}=15, n_{\text {обследований }}=25\right)$; 3-я - дети с ГБ типа VI и IX $\left(n_{\text {детей }}=19, n_{\text {обследований }}=38\right)$. Группу сравнения составили 34 условно здоровых ребенка $\left(n_{\text {обследований }}=107\right)$, сопоставимые по полу и возрасту с основной группой.

\section{Методы исследования}

Всем детям было проведено определение активности внутриклеточных дегидрогеназ лимфоцитов (СДГ, НАДН-Д, ЛДГ, ГФДГ) методом количественного цитохимического анализа, включающего световую микроскопию и цитоморфоденситометрию.

Активность ГФДГ определяли количественным цитохимическим методом, основанном на способности паранитротетразолия фиолетового в процессе ферментативной реакции образовывать не растворимые в воде круглые гранулы формазана в лейкоцитах и тромбоцитах периферической крови [22]. Активность фермента при световой микроскопии оценивали в числеобразованных гранул на клетку (гр./кл.).

Активность СДГ, НАДН-Д и ЛДГ оценивали цитоморфоденситометрическим методом, который проводили с помощью аппаратно-программного комплекса

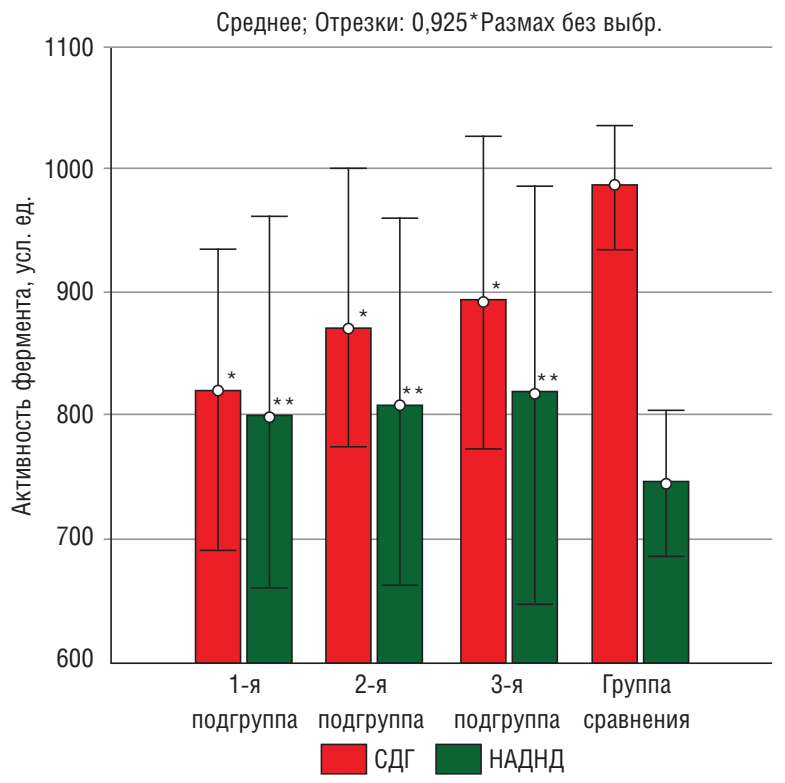

Рис. 1. Активность сукцинат- и никотинамидаденин-Ндегидрогеназы лимфоцитов у пациентов 1-й, 2-й и 3-й подгруппы по отношению к группе сравнения.

Примечание. Здесь и на рис. $2,3{ }^{*}-p<0,001,{ }^{* *}-p<0,05$. визуализации морфологических препаратов, анализа и регистрации оптических и морфологических показателей «ВидеоТест» и программы «Морфология 5.2» (Россия) [23]. Цитоморфоденситометрический анализ, помимо числа гранул в клетке, позволяет оценить их площадь и оптическую плотность. Оценка активности фермента при помощи данного метода исследования учитывает все эти характеристики и представлена в виде интегральной оптической плотности, измеренной в условных единицах (усл.ед.).

\section{Статистическая обработка данных}

Статистический анализ полученных результатов проводился с использованием пакета программ STATISTICA v. 6.0 (StatSoft Inc, CША). Данные представлены в виде медианы и [нижней-верхней] квартили. Достоверность отличий оценивали при помощи непараметрического критерия Колмогорова-Смирнова. Корреляционный анализ проводили методом пошаговой регрессии. Различия считали статистически значимыми при $p<0,05$.

\section{Результаты}

Было обнаружено достоверное снижение активности СДГ при всех типах ГБ по отношению к группе сравнения (табл., рис. 1). При этом наиболее выраженное снижение активности СДГ ( $p<0,001)$ отмечено в 1 -й подгруппе пациентов, что соотносится с более тяжелым клиническим течением ГБ типа I у детей. Во 2-й подгруппе (ГБ типа III) снижение активности СДГ было менее выражено $(p<0,001)$. Наименьшее отклонение этого показателя от такового в группе сравнения наблюдали в 3-й подгруппе (ГБ типа VI) $(p<0,05)$. При этом достоверных различий в активности СДГ между тремя подгруппами пациентов выявлено не было.

Напротив, активность НАДН-Д у детей основной группы была достоверно выше таковой в группе сравнения $(p<0,05)$. Ее показатели между подгруппами также не различались (см. табл., рис. 1).

Как видно из табл. 1, у пациентов с ГБ имело место нарушение соотношения между СДГ и НАДН-Д. Так, если в группе сравнения активность СДГ существенно превышала таковую НАДН-Д, и медиана индекса их соотношения составляла 1,35 [1,20-1,42], то во всех подгруппах детей с ГБ наблюдали достоверное снижение этого индекса $(p<0,001)$. Между группами данный показатель не различался.

Одновременно нами было обнаружено значительное $(p<0,001)$ снижение активности ГФДГ во всех подгруппах детей, страдающих ГБ (рис. 2), что отражает низкую сопряженность цикла Кребса и гликолиза у этих пациентов.

Как видно из представленных данных, активность ГФДГ во всех подгруппах была снижена в среднем на $48 \%$ по сравнению с группой сравнения, однако статистически достоверных различий между активностью фермента в разных подгруппах зарегистрировано не было. 


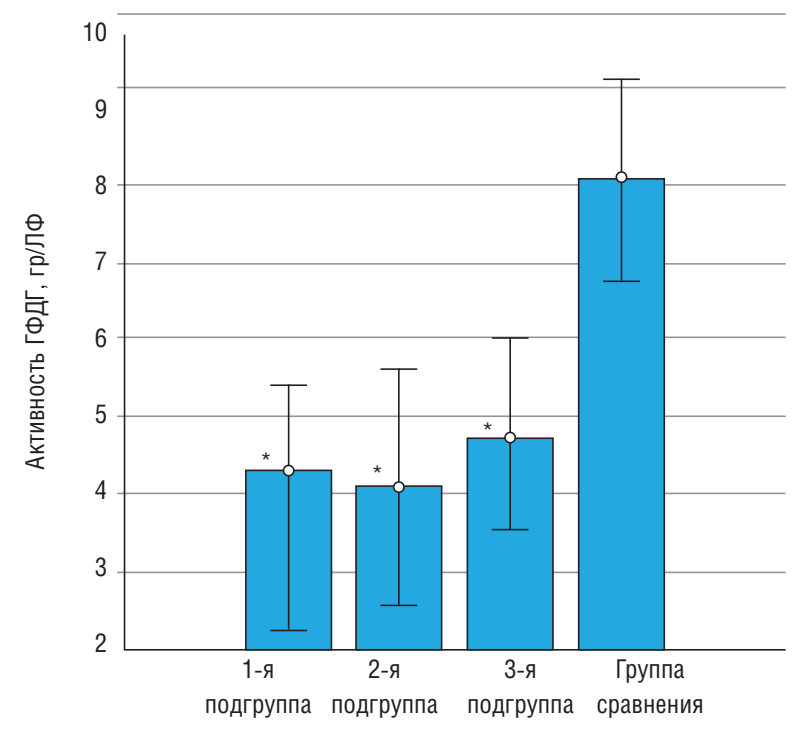

Рис. 2. Активность глицерол-3-фосфатдегидрогеназы у пациентов 1-й, 2-й и 3-й подгруппы по отношению к группе сравнения.

В то же время активность ЛДГ была повышена в 1-й и 3-й подгруппе ( $p<0,05$ и $p<0,001$, соответственно) по отношению к группе сравнения (рис. 3). Данный факт может свидетельствовать об активации анаэробного гликолиза у пациентов с ГБ на фоне депрессии окислительного фосфорилирования. При этом у детей 2-й подгруппы достоверных отличий от группы сравнения не выявили.

Нами был проведен корреляционный анализ с целью определения взаимосвязей между традиционными клинико-лабораторными параметрами, позволяющими оценить тяжесть состояния пациентов с ГБ, и активностью исследованных внутриклеточных ферментов лимфоцитов.

Одним из основных клинических критериев оценки тяжести состояния пациента с ГБ является выраженность гепатомегалии. Вследствие нарушения процессов метаболизма в печени у таких пациентов происходит накопление различных продуктов обмена: углеводов (в основном, гликогена), жиров, железа и т.п., которые приводят к ее увеличению. В результате дистрофии и воспалительных изменений происходит разрушение гепатоцитов, на месте которых формируется соединительная ткань, что приводит к фиброзу, и, в конечном итоге, к циррозу печени $[1,5]$.

Лабораторным критерием оценки степени тяжести состояния пациентов с ГБ может послужить дефицит буферных оснований (Base-Excess, BE): отклонение концентрации буферных оснований от нормального уровня. В норме показатель ВЕ равен 0 ммоль/л, а допустимые пределы его колебаний составляют $\pm 2,3$ ммоль/л. Величина ВЕ является наиболее информативным показателем метаболических нарушений кислотно-основного состояния. Дефицит оснований свидетельствует о наличии метаболического ацидоза.

У пациентов с ГБ на фоне повышения сывороточного уровня лактата, являющегося органической кислотой, возникает ацидемия, и развивается хронический метаболический ацидоз, в результате чего происходит постепенное истощение буферных систем (в первую очередь, гидрокарбонатной) и физиологических механизмов нейтрализации и выведения избытка нелетучих кислот из ор-

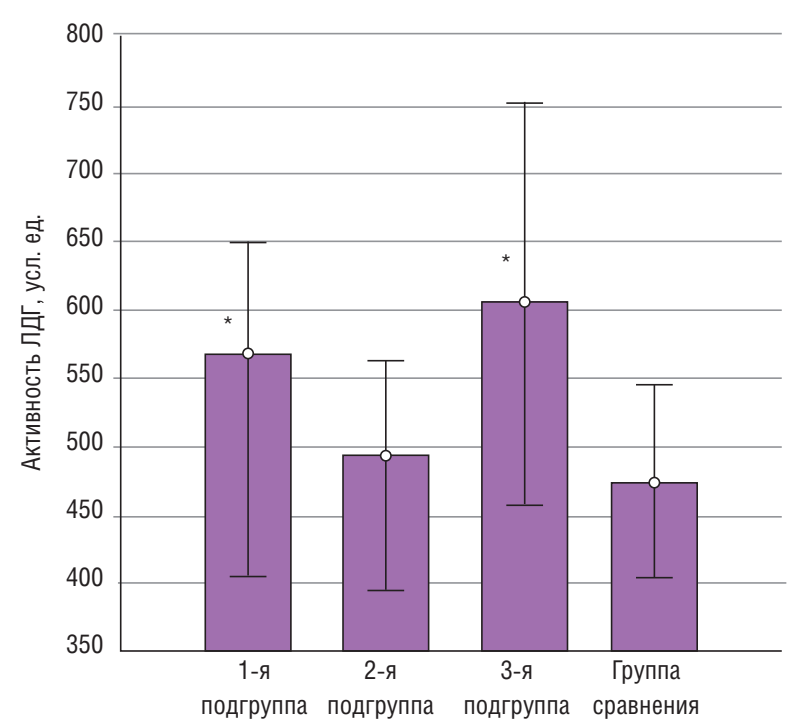

Рис. 3. Активность лактатдегидрогеназы лимфоцитов у пациентов 1-й, 2-й и 3-й подгруппы по отношению к группе сравнения.

ганизма. При прогрессировании ГБ, сопровождающемся длительным снижением $\mathrm{pH}$ крови и истощением натрийбикарбонатной буферной системы, начинает задействоваться депо кальция и фосфатов костной ткани в связи с необходимостью нейтрализации катионов кислот. Такая адаптация к ацидозу приводит к опасной деминерализации эмали зубов и костей и, итоге, к остеопорозу [1, 5].

Выявленные корреляции представлены на рис. 4 $(\mathrm{a}$, б) и $5(\mathrm{a}$, б).

Установленные связи между активностью исследованных нами дегидрогеназ лимфоцитов и важнейшими клинико-лабораторными характеристиками течения заболевания доказывают информативность и объективность цитохимических показателей в оценке тяжести состояния детей с ГБ. Особое значение для практической медицины имеет изучение указанных нарушений в связи с разработкой в этой области эффективных методов терапевтической коррекции.

\section{Обсуждение}

Современный этап изучения ГБ характеризуется наличием многих нерешенных вопросов. В частности, существует проблема скрининга данной патологии в раннем возрасте и мониторинга состояния таких больных. Затруднена дифференциальная диагностика типов ГБ в связи с малой доступностью и высокой стоимостью молекулярно-генетического анализа [5]. При этом, как уже говорилось, на фоне хронической персистирующей гипогликемии у детей с ГБ развивается выраженная метаболическая декомпенсация, ведущая к значительному ухудшению состояния больных.

Жирные кислоты, моносахариды и аминокислоты являются предшественниками пирувата и ацетил-КоА универсальных двухуглеродных соединений, поступающих в цикл Кребса - циклический биохимический аэробный процесс, основной этап жизнедеятельности всех клеток, использующих в своей жизнедеятельности кислород. Цикл Кребса играет ключевую роль в процессах глюконеогенеза, переаминирования, дезаминирования и липогенеза [5]. 


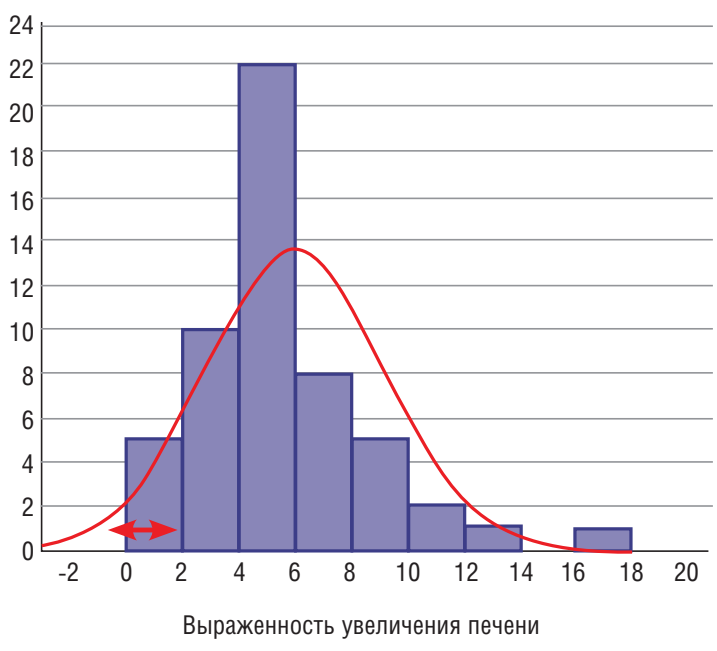

a

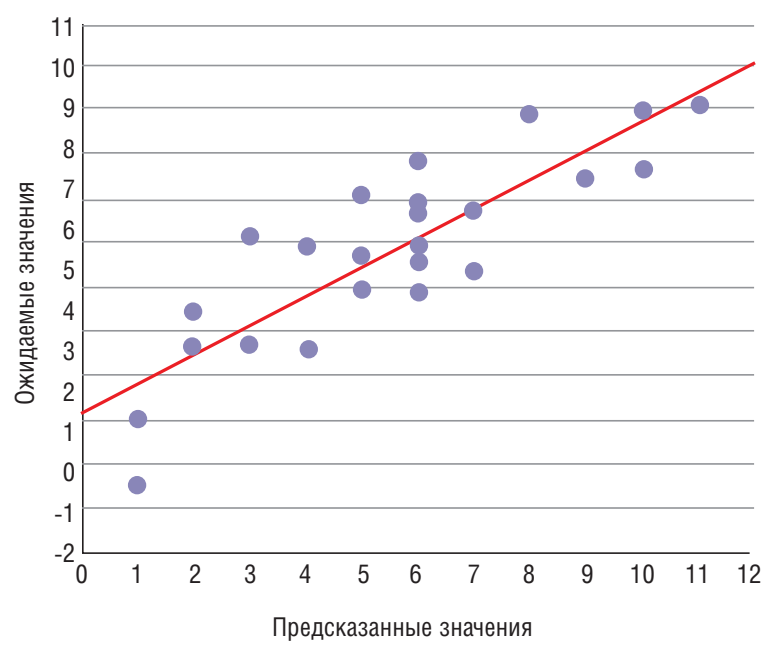

Рис. 4. Распределение больных с гликогеновой болезнью в зависимости от степени выраженности гепатомегалии, см.

Примечание. (а) Двухконечной стрелкой показаны референсные значения: от 0 до 2 см (б) Корреляции между выраженностью гепатомегалии и активностью СДГ, НАДН-Д, ЛДГ, ГФДГ лимфоцитов, коэффициент множественной корреляции $\mathrm{R}=0,86$.

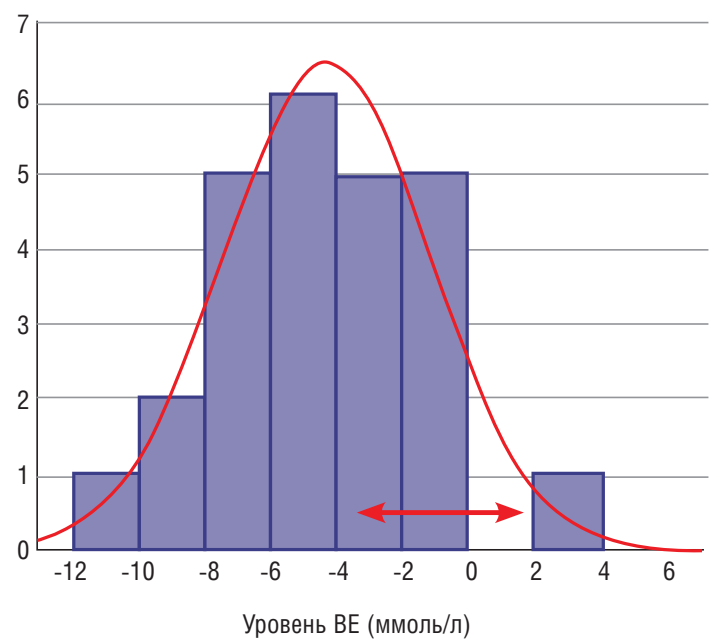

a

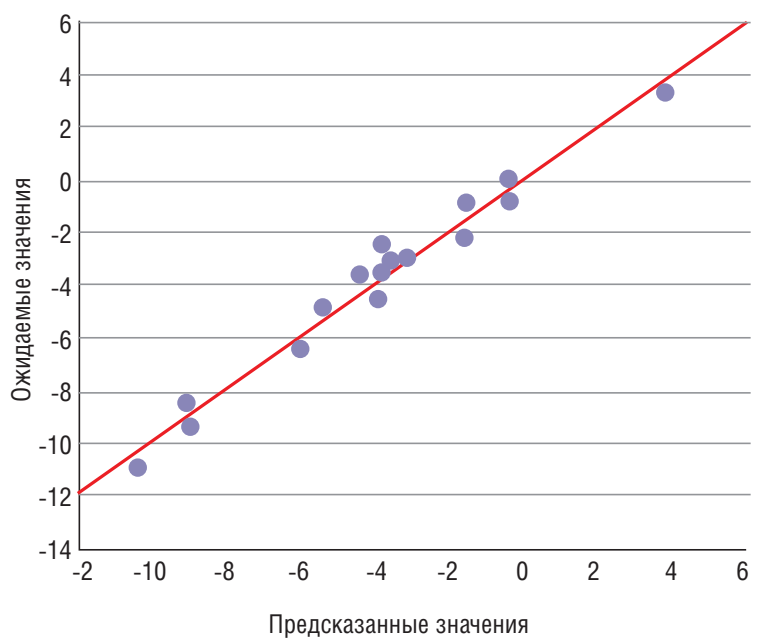

б

Рис. 5. Распределение больных в зависимости от уровня дефицита оснований (BЕ) в сыворотке крови, ммоль/л.

Примечание. (а) Двухконечной стрелкой показаны референсные значения: от -2 до +2 ммоль/л. (б) Корреляции между значением ВЕ и активностью СДГ, НАДН-Д, ЛДГ, ГФДГ лимфоцитов, коэффициент множественной корреляции $\mathrm{R}=0,987$.

Полученные в цикле Кребса восстановительные эквиваленты переносятся на НАД ${ }^{+}$или убихинон и включаются в дыхательную цепь, являющуюся частью процесса окислительного фосфорилирования. Компоненты дыхательной цепи катализируют перенос электронов от $\mathrm{HАДH}^{+} \mathrm{H}^{+}$или восстановленного убихинона на молекулярный кислород. Из-за большой разницы окислительно-восстановительных потенциалов донора и акцептора реакция является высокоэкзергонической. Большая часть выделяющейся при этом энергии используется для создания градиента протонов и образования АТФ с помощью АТФ-синтазы [23].

Механизм регуляции образования и потребления АТФ называется дыхательным контролем, который основан на сопряжении поступления и расходования коферментов. Если клетка не расходует АТФ, то не происходит и нарастание АДФ, что, в свою очередь, тормозит электронный перенос в дыхательной цепи, вследствие чего НАДН не может быть окислен в НАД ${ }^{+}$. В этом случае возникающее высокое соотношение НАДН / НАД ${ }^{+}$тормозит цитратный цикл и тем самым снижает потребление субстрата. Если создание протонного градиента подавлено, то процессы окисления субстрата и переноса электронов протекают значительно быстрее, чем обычно. При этом вместо синтеза АТФ выделяется тепло. При избыточном количестве жирных кислот, которые распадаются в результате $\beta$-окисления, и недостатке пирувата в дыхательной цепи открывается протонный канал, не зависящий от наличия АДФ. Распад жирных кислот протекает с максимальной скоростью, генерируя энергию в форме тепла, а не в форме АТФ [23].

К настоящему моменту доказано, что митохондриальный аппарат отвечает за многие функции, контролирующие жизнедеятельность клетки. Помимо ведущей роли 
в процессе образования энергии, митохондрия позиционируется как органелла, регулирующая посредством образования активных форм кислорода процессы клеточной пролиферации и дифференцировки. Также одной из функций митохондрии является проведение нервного импульса за счет модулирования гомеостаза $\mathrm{Ca}^{2+}$ и участия в образовании $\gamma$-аминомасляной кислоты и глутамата [6]. Митохондриальный белок MAVS (mitochondrial antiviral signaling) опосредует активацию транскрипционного фактора NF-kB (nuclear factor kB) и интерферон-регулирующего фактора IRF3 (interferon regulatory factor 3) при распознавании вирусной инфекции, peгулируя образование интерферона $\beta$ (IFN $\beta$ ) $[7,8]$. Структурные дефекты таких митохондриальных ферментов, как сукцинат-, фумарат- и изоцитратдегидрогеназа могут быть причиной развития опухолевых процессов [6].

A. Garcia-Cazorla и соавт. (2006) показали, что нарушение активности дыхательной цепи митохондрий были связаны с заболеваниями печени различной степени тяжести у младенцев и детей старшего возраста, причем у $52 \%$ из них имелась гиперлактатемия. Авторы предлагают использовать биопсию печени для исключения патологических состояний, сопровождающихся дефектами митохондриальной цепи [21].

Биопсия печени является «золотым стандартом» диагностики и при ГБ, позволяя обнаружить ряд специфических морфологических особенностей, характерных для данной патологии, а также провести количественное определение содержания гликогена в сыром веществе печени $[1,5]$. Однако эта процедура инвазивна и сопровождается болезненными ощущениями, имеет риск развития осложнений, в связи с чем применение данной методики в педиатрической практике ограничено и имеет ряд противопоказаний $[1,5]$. При этом гистологическая картина печени не всегда позволяет оценить выраженность метаболических изменений, в связи с чем сушествует потребность в поиске малоинвазивных методик, дающих представление о состоянии пациента, страдающего ГБ. К одной из них может быть отнесен и цитохимический анализ крови. Р.П. Нарциссовым и соавт. (1999) показано, что ферментный статус лимфоцитов отражает состояние клеток практически всех тканей организма: мозга, миокарда, печени, почек, селезенки, тимуса, мышц, слизистой оболочки желудка и кишечника [24].
Г.Ф. Суслова (1991) с помощью количественного гистохимического метода проводила определение активности дегидрогеназ, в частности, СДГ, НАДН-Д, ГФДГ, в различных органах, в т.ч. в печени, у детей с хроническими гепатитами и циррозом. Автором было установлено, что активность этих ферментов в срезах печеночной ткани коррелирует с таковой в лимфоцитах периферической крови. Кроме того, ей же было показано, что при патологии печени у детей ферментный статус лимфоцитов и тромбоцитов крови коррелирует с сывороточными уровнями печеночных трансаминаз, билирубина, холестерина, перкуторными размерами печени. По ферментному статусу клеток крови можно прогнозировать исход заболевания [25].

Результаты нашего исследования, впервые проведенного у детей с ГБ в Российской Федерации, согласуются с вышеизложенными фактами и доказывают высокую информативность определения ферментного статуса лимфоцитов крови у таких пациентов, что подтверждается четкими корреляциями этих показателей с основными клинико-лабораторными параметрами оценки степени тяжести состояния больного [26].

\section{Заключение}

У детей с печеночными формами ГБ обнаружены признаки митохондриальной дисфункции, степень выраженности которых зависит от типа заболевания. Митохондриальная дисфункция наиболее выражена у пациентов с ГБ типа I, что соотносится с тяжестью состояния пациентов ввиду особенностей патогенеза болезни.

Активность ферментов лимфоцитов у детей с ГБ коррелирует с основными параметрами оценки тяжести состояния, что позволяет использовать данные показатели в качестве дополнительных диагностических критериев.

Дальнейшие исследования должны быть посвящены изучению влияния метаболических препаратов на компенсацию выявленных митохондриальных нарушений у пациентов с ГБ.

\section{Конфликт интересов}

Авторы данной статьи подтвердили отсутствие финансовой поддержки / конфликта интересов, который необходимо обнародовать.

\section{ЛИТЕРАТУРА}

1. Сурков А.Н., Потапов А.С., Лозоватор А.Л., Туманова Е.Л. Особенности морфологических изменений печени у детей с гликогеновой болезнью. Вопр. совр. педиатрии. 2013; 12 (6): 24-28.

2. Froissart R., Piraud M., Boudjemline A.M., Vianey-Saban C., Petit F., Hubert-Buron A., Eberschweiler P.T., Gajdos V., Labrune P. Glucose-6-phosphatase deficiency. Orphanet J. Rare Dis. 2011; 20 (6): 27.

3. Ozen H. Glycogen storage diseases: new perspectives. World J. Gastroenterol. 2007; 13 (18): 2541-2553.

4. Labrune P., Eberschweiler P.T., Boudjemline A.M., Hubert-Buron A., Petit F., Gajdos V. Natural history of hepatic glycogen storage diseases. Presse Med. 2008; 37 (7-8): 1172-1177.

5. Баранов А.А, Намазова-Баранова Л.С, Сурков А.Н., Потапов А.С., Баканов М.И., Полякова С.И., Гундобина О.С., Лозоватор А.Л. Гликогеновая болезнь у детей: учебное пособие. M.: Педиатр В. 2012. 127 с

6. Nunnari J., Suomalainen A. Mitochondria: in sickness and health. Cell. 2012; 148 (6): 1145-1159.
7. Scott I. The role of mitochondria in the mammalian antiviral defense system. Mitochondrion. 2010; 10 (4): 316-320.

8. Cloonan S.M., Choi A.M. Mitochondria: commanders of innate immunity and disease? Curr. Opin. Immunol. 2012; 24 (1): 32-40

9. Pagliarini D.J., Rutter J. Hallmarks of a new era in mitochondrial biochemistry. Genes Dev. 2013; 27 (24): 2615-2627.

10. Koopman W.J., Willems P.H., Smeitink J.A. Monogenic mitochondrial disorders. N. Engl. J. Med. 2012; 366 (12): 1132-1141.

11. Царегородцев А.Д., Сухоруков В.С. Митохондриальная медицина - проблемы и задачи. Росс. вестн. перинатол. и педиатрии. 2012; 4: 4-13

12. Лукьянова Л.Д., Кирова Ю.И., Сукоян Г.В. Новое о сигнальных механизмах адаптации к гипоксии и их роли в системной регуляции. Патогенез. 2011; 9 (3): 4-14.

13. Капустина Е.Ю. Активность митохондриальных ферментов лимфоцитов периферической крови у детей с респираторными и кожными проявлениями аллергии. Автореф. дис.... канд. мед. наук. M. 2006. 26 с. 
14. Писарева И.В. Изменения активности внутриклеточных ферментов лимфоцитов при аппендикулярном перитоните у детей. Автореф. дис.... канд. мед. наук. 2007. М. 25 с.

15. Климова С.В. Клиническое значение активности митохондриальных ферментов лимфоцитов при воспалительных заболеваниях кишечника у детей. Автореф. дис.... канд. мед. наук. M. 2010. $26 \mathrm{c}$.

16. Schon E.A, DiMauro S., Hirano M. Human mitochondrial DNA: roles of inherited and somatic mutations. Nat. Rev. Genet. 2012; 13 (12): 878-890.

17. Rutter J., Winge D.R., Schiffman J.D. Succinate dehydrogenase assembly, regulation and role in human disease. Mitochondrion. 2010; 10 (4): 393-401.

18. Tobon A. Metabolic myopathies. Continuum (Minneap. Minn.). 2013; 19 (6): 1571-1597.

19. Alzoghaibi M.A. Concepts of oxidative stress and antioxidant defense in Crohn's disease. World J. Gastroenterol. 2013; 19 (39): 6540-6547.

20. Dimauro S., Garone C. Metabolic disorders of fetal life: glycogenoses and mitochondrial defects of the mitochondrial respiratory chain. Semin. Fetal. Neonatal. Med. 2011; 16 (4): 181-189.
21. Garcia-Cazorla A., De Lonlay P., Rustin P., Chretien D., Touati G., Rabier D., Slama A., Saudubray J.M. Mitochondrial respiratory chain deficiencies expressing the enzymatic deficiency in the hepatic tissue: a study of 31 patients. J. Pediatr. 2006; 149 (3): 401-405.

22. Петричук С.В., Шищенко В.М., Духова 3.Н., Измайлова Т.Д., Писарева И.В., Поляков С.Д., Корнеева И.Т. Диагностические и прогностические возможности клинической цитохимии. М. $2005.75 \mathrm{c}$.

23. Кольман Я., Рём К.Г. Наглядная биохимия. М.: Мup. 2000. 469 с.

24. Нарциссов Р.П., ред., Шищенко В.М., Петричук С.В., Духова 3.Н., Семёнова Г.Ф. Здоровье, болезнь и лекарство (цитохимическая экспертиза с помощью анализатора изображений). M. 1999.25 с.

25. Суслова Г.Ф. Динамика ферментного статуса клеток и тканей при болезнях органов пищеварения. Автореф. дис. ... докт. биол. наук. М. 1991. $31 \mathrm{c.}$

26. Kurbatova O., Surkov A., Polyakova S., Miroshkina L., Semenova G., Samokhina I., Izmailova T., Kapustina E., Dukhova Z., Zakirov R., Freydlin E., Petrichuk S. Lymphocytes intracellular enzymes activity in children with hepatic form of glycogen storage disease. $J$. Inher. Metab. Dis. 2013; 36 (Suppl. 2): 226.

\section{КОНТАКТНАЯ ИНФОРМАЦИЯ}

Курбатова Ольга Владимировна, научный сотрудник лаборатории цитохимии Научного центра здоровья детей. Адрес: 119991, Москва, Ломоносовский проспект, д. 2, стр. 1, тел.: +7 (495) 967-14-20, e-mail: putintseva@mail.ru Измайлова Татьяна Дмитриевна, кандидат медицинских наук, старший научный сотрудник лаборатории цитохимии Научного центра здоровья детей.

Адрес: 119991, Москва, Ломоносовский проспект, д. 2, стр. 1, тел.: +7 (495) 967-14-20, e-mail: izmajlova68@mail.ru Сурков Андрей Николаевич, кандидат медицинских наук, старший научный сотрудник отдела планирования и прогнозирования научных исследований Научного центра здоровья детей.

Адрес: 119991, Москва, Ломоносовский проспект, д. 2, стр. 1, тел.: +7 (499) 134-02-76, e-mail: surkov@nczd.ru Полякова Светлана Игоревна, доктор медицинских наук, ведущий научный сотрудник гастроэнтерологического отделения с гепатологической группой Научного центра здоровья детей.

Адрес: 119991, Москва, Ломоносовский проспект, д. 2, стр. 1, тел.: +7 (495) 967-14-20, e-mail: polyakova1963@list.ru

Намазова-Баранова Лейла Сеймуровна, доктор медицинских наук, профессор, член-корреспондент РАМН, заместитель директора-директор НИИ профилактической педиатрии и восстановительного лечения Научного центра здоровья детей.

Адрес: 119991, Москва, Ломоносовский проспект, д. 2, стр. 1, тел.: +7 (495) 967-14-20, e-mail: namazova@nczd.ru Мирошкина Любовь Владимировна, младший научный сотрудник лаборатории цитохимии Научного центра здоровья детей.

Адрес: 119991, Москва, Ломоносовский проспект, д. 2, стр. 1, тел.: +7 (495) 967-14-20, e-mail: kyuzi@mail.ru Семёнова Галина Федоровна, доктор биологических наук, ведущий научный сотрудник лаборатории цитохимии Научного центра здоровья детей.

Адрес: 119991, Москва, Ломоносовский проспект, д. 2, стр. 1, тел.: +7 (495) 967-14-20, e-mail: cito@list.ru

Самохина Ирина Валериевна, кандидат медицинских наук, научный сотрудник лаборатории цитохимии Научного центра здоровья детей.

Адрес: 119991, Москва, Ломоносовский проспект, д. 2, стр. 1, тел.: +7 (495) 967-14-20, e-mail: irine 2002@mail.ru Капустина Екатерина Юрьевна, кандидат медицинских наук, научный сотрудник лаборатории цитохимии Научного центра здоровья детей.

Адрес: 119991, Москва, Ломоносовский проспект, д. 2, стр. 1, тел.: +7 (495) 967-14-20, e-mail: dr-kapustina@yandex.ru Духова Зоя Николаевна, кандидат медицинских наук, научный сотрудник лаборатории цитохимии Научного центра здоровья детей.

Адрес: 119991, Москва, Ломоносовский проспект, д. 2, стр. 1, тел.: +7 (495) 967-14-20, e-mail: cito@list.ru

Потапов Александр Сергеевич, доктор медицинских наук, профессор, заведующий гастроэнтерологическим отделением с гепатологической группой Научного центра здоровья детей.

Адрес: 119991, Москва, Ломоносовский проспект, д. 2, стр. 1, тел.: +7 (495) 967-14-20, e-mail: apotap@mail.ru Петричук Светлана Валентиновна, доктор биологических наук, заведующая лабораторией цитохимии Научного центра здоровья детей.

Адрес: 119991, Москва, Ломоносовский проспект, д. 2, стр. 1, тел.: +7 (495) 967-14-20, e-mail: cito@list.ru 